\title{
PUTUSAN LEPAS DARI SEGALA TUNTUTAN HUKUM TERHADAP PELAKU KEKERASAN DALAM RUMAH TANGGA YANG MENYEBABKAN KEMATIAN (Studi Kasus Terhadap Putusan Perkara Nomor 16/ PID.B/2011/PN.BLK) IDA ZULFAMAZIDAH \\ Hakim Pengadilan Negeri Purwodadi Ida.zulfa07@gmail.com
}

\begin{abstract}
The application of criminal removal is a very important matter in the judgment. When consideration of improper judgment errors will obscure the essence of judicial and criminal law purposes. The purpose of this research is to analyze the application of criminal removal reasons based on Article 44 of the Criminal Code on judges' consideration in breaking free from all lawsuits against perpetrators of domestic violence that led to the death of Decision No. 16 / PID.B / 2011 / PN.BLK and also analyzing the suitability Consideration of the judge on the decision of the case with the purpose of criminal law. This research was conducted normatively and obtained the result that the Panel of Judges in breaking out of all lawsuits against perpetrators of domestic violence that led to death in the case Number 16 / PID.B / 2011 / PN.BLK using expert information that is psychiatrist as the only The basis for determining criminal responsibility or known by biological methods. Decision Number 16 / PID.B / 2011 / PN.BLK has been in accordance with the purpose of criminal law, one of which is achieved legal certainty, especially for the perpetrator.
\end{abstract}

Key words : Decision, Out of all lawsuits, Article 44 of the Criminal Code.

\begin{abstract}
ABSTRAK
Penerapan alasan penghapus pidana merupakan suatu hal yang sangat penting dalam penjatuhan putusan. Ketika pertimbangan penjatuhan putusan terjadi kesalahan akan mengaburkan esensi peradilan dan tujuan hukum pidana. Tujuan penelitian ini untuk menganalisis penerapan alasan penghapus pidana berdasarkan Pasal 44 KUHP pada pertimbangan hakim dalam memutus lepas dari segala tuntutan hukum terhadap pelaku kekerasan dalam rumah tangga yang menyebabkan kematian pada putusan Nomor 16/ PID.B/2011/PN.BLK dan juga menganalisis kesesuaian pertimbangan hakim pada putusan perkara tersebut dengan tujuan hukum pidana. Penelitian ini dilakukan secara normatif dan diperoleh hasil bahwa Majelis Hakim dalam memutus lepas dari segala tuntutan hukum terhadap pelaku kekerasan dalam rumah tangga yang menyebabkan kematian pada perkara Nomor 16/ PID.B/2011/PN.BLK menggunakan keterangan ahli yaitu psikiater sebagai satu-satunya landasan untuk menentukan pertanggungjawaban pidana atau dikenal dengan metode biologis. Putusan Nomor 16/ PID.B/2011/PN.BLK telah sesuai dengan tujuan hukum pidana salah satunya tercapai kepastian hukum terutama bagi pelaku.
\end{abstract}

KATA KUNCI : Putusan, Lepas dari segala tuntutan hukum

\section{A. PENDAHULUAN}

Terdakwa SAMAD Bin RABA menyerang keluarganya sendiri tanpa alasan yang jelas sehingga mengakibatkan PANNO Binti KARETA

meninggal dunia. Setelah melalui proses hukum sampai dengan persidangan, Majelis Hakim Pengadilan Negeri Bulukumba pemeriksa perkara Nomor 16/PID.B/2011/PN.BLK memutus

Terdakwa dengan putusan lepas dari 
segala tuntutan hukum. Putusan yang diucapkan pada tanggal 20 April 2011 tersebut menyatakan bahwa Terdakwa SAMAD Bin RABA, terbukti menurut hukum melakukan perbuatan sebagaimana didakwakan kepadanya namun Terdakwa pada waktu melakukan perbuatannya tersebut dalam keadaan tidak mampu untuk bertanggung jawab oleh karena adanya gangguan jiwa.

Salah satu kesulitan Hakim dalam proses peradilan pidana adalah menentukan apakah Terdakwa yang melakukan tindak pidana dapat dipertanggungjawabkan, sehingga dapat dijatuhi pidana. Perbuatan pidana mempunyai arti kalau disampingnya adalah pertanggungjawaban, sebaliknya tidak mungkin ada pertanggungjawaban jika tidak ada perbuatan pidana. Kesalahan adalah unsur bahkan syarat mutlak bagi adanya pertanggungjawaban yang berupa pengenaan pidana. Bagi masyarakat Indonesia berlaku asas tidak dipidana jika tidak ada kesalahan "Geen straf zonder schuld", "Keine strafe ohne Schuld" atau dalam bahasa atinnya "Actus non facit reum nisi mens sit rea" (an act does not make aperson guilty unless his mind is guilty). ${ }^{1}$

Ketentuan tentang arti kemampuan bertanggung jawab tidak ada dalam KUHP. Menurut Moeljatno, yang berhubungan dengan kemampuan bertanggung jawab ialah Pasal 44

${ }^{1}$ Moeljatno, 1983, Perbuatan Pidana dan Pertanggungjawaban dalam Hukum Pidana.Bina Aksara, Yogyakarta, hlm. 25.
KUHP "Barangsiapa melakukan perbuatan yang tidak dapat dipertanggungjawabkan kepadanya, karena jiwanya cacat dalam tubuhnya atau jiwa yang terganggu karena penyakit", kalau tidak dapat dipertanggungjawabkannya itu disebabkan karena hal lain, misalnya jiwanya tidak normal karena masih sangat muda atau lain-lain, pasal tersebut tidak dapat dipakai. ${ }^{2}$ Pada KUHP terjemahan R. Soesilo, Pasal 44 ayat (1) KUHP berbunyi "Barangsiapa mengerjakan sesuatu perbuatan, yang tidak dapat dipertanggungkan kepadanya karena kurang sempurna akalnya atau karena sakit berubah akal tidak boleh dihukum". 3

Pada dasarnya, kehadiran hukum pidana di tengah masyarakat dimaksudkan untuk memberikan rasa aman kepada individu maupun kelompok dalam masyarakat dalam melaksanakan aktifitas kesehariannya. Rasa aman yang dimaksudkan dalam hal ini adalah perasaan tenang, tanpa ada kekhawatiran akan ancaman ataupun perbuatan yang dapat merugikan antar individu dalam masyarakat. ${ }^{4}$ Untuk dapat dipidananya si pelaku, diharuskan tindak pidana yang

2 Moeljatno, 2008, Asas-Asas Hukum Pidana Edisi Revisi, PT Rineka Cipta, Jakarta, hlm 178.

${ }^{3}$ R. Soesilo, 1996, Kitab Undang-Undang Hukum Pidana (KUHP) Serta KomentarKomentarnya Lengkap Pasal Demi Pasal, Politeia, Bogor, hlm. 60.

${ }^{4}$ Amir Ilyas, 2012. Asas-asas Hukum Pidana, Rangkang Education Yogyakarta \& PuKAP-Indonesia, Yogyakarta, hlm. 1-2. 
dilakukannya itu memenuhi unsur-unsur delik yang telah ditentukan dalam Undang-undang.

Dilihat dari sudut terjadinya tindakan yang dilarang, seseorang akan dipertanggungjawabkan atas tindakantindakan tersebut, apabila tindakan tersebut melawan hukum serta tidak ada alasan pembenar atau peniadaan sifat melawan hukum untuk pidana yang dilakukannya. Dan dilihat dari sudut kemampuan bertanggung jawab maka hanya seseorang yang mampu bertanggung jawab yang dapat dipertanggungjawabkan atas perbuatannya. $^{5}$

Penerapan alasan penghapus pidana merupakan suatu hal yang sangat penting dalam penjatuhan putusan. Ketika pertimbangan penjatuhan putusan terjadi kesalahan tentunya akan mengaburkan suatu esensi peradilan dan tujuan hukum pidana. Untuk itu perlu dikaji pertimbangan Hakim dalam memutus lepas dari segala tuntutan hukum terhadap pelaku kekerasan dalam rumah tangga yang menyebabkan kematian pada putusan perkara Nomor 16/ PID.B/2011/PN.BLK serta kesesuaian pertimbangan Hakim dalam perkara tersebut dengan tujuan hukum pidana.

\footnotetext{
${ }^{5}$ Ibid., hlm. 73.
}

\section{B. PERUMUSAN MASALAH}

Berdasarkan uraian diatas dapat diambil suatu rumusan masalah yaitu sebagai berikut :

1. Bagaimana penerapan alasan penghapus pidana berdasarkan Pasal 44 KUHP pada pertimbangan Hakim dalam memutus lepas dari segala tuntutan hukum terhadap pelaku kekerasan dalam rumah tangga yang menyebabkan kematian pada putusan perkara Nomor 16/ PID.B/2011/PN.BLK?

2. Apakah Hakim dalam memutus lepas dari segala tuntutan hukum terhadap pelaku kekerasan dalam rumah tangga yang menyebabkan kematian pada putusan perkara Nomor 16/ PID.B/2011/PN.BLK sesuai dengan tujuan hukum pidana?

\section{METODE PENELITIAN}

Metode pendekatan yang digunakan dalam tulisan ini adalah metode pendekatan hukum normatif/doktrinal, menggunakan spesifikasi penelitian deskriptif yaitu suatu penelitian yang menggambarkan keadaan obyek yang akan diteliti. ${ }^{6}$ Sumber data yang dipergunakan adalah sumber data sekunder yang terdiri dari bahan hukum primer dan bahan hukum

\footnotetext{
${ }^{6}$ Bambang Sunggono, 2006, Metode Penelitian Hukum, PT Raja Grafindo Persada, Jakarta, hlm 35.
} 
sekunder. ${ }^{7}$ Bahan Hukum Primer berupa peraturan perundangundangan, yang digunakan adalah KUHP, UU No. 8 tahun 1981 tentang Kitab Undang-undang Hukum Acara Pidana (KUHAP), UU RI No. 23 Tahun 2004 tentang Penghapusan Kekerasan Dalam Rumah Tangga, Undang-Undang Nomor 48 Tahun 2009 tentang Kekuasaan Kehakiman. Sedangkan bahan hukum sekunder berupa hasil karya dari kalangan hukum dalam bentuk buku-buku atau artikel.

Metode pengumpulan data yang digunakan adalah dengan studi kepustakaan atau studi dokumen. Kemudian disajikan dalam bentuk uraian teks naratif yang disusun secara sistematis. Dalam arti keseluruhan data yang diperoleh akan dihubungkan satu dengan yang lainnya disesuaikan dengan pokok permasalahan yang diteliti, sehingga merupakan satu kesatuan yang utuh. Selanjutnya dianalisis dengan metode kualitatif, yaitu menguraikan data secara bermutu, dalam bentuk kalimat yang teratur, runtun, logis, tidak tumpang tindih dan efektif, dan kemudian dilakukan pembahasan.

\section{PEMBAHASAN}

1. Penerapan alasan penghapus pidana berdasarkan Pasal 44 KUHP pada pertimbangan Hakim dalam memutus lepas dari segala tuntutan hukum terhadap pelaku kekerasan dalam rumah tangga yang menyebabkan kematian pada putusan perkara Nomor 16/ PID.B/2011/PN.BLK

\begin{tabular}{lrr}
\multicolumn{1}{c}{ Majelis } & Hakim \\
Pengadilan & & Negeri \\
Bulukumba & pemeriksa \\
perkara Nomor & 16/ \\
PID.B/2011/PN.BLK
\end{tabular}
mendasarkan putusannya menggunakan Pasal 44 KUHP dalam pertimbangan hukumnya.Jadi, meskipun Terdakwa SAMAD Bin RABA terbukti melakukan perbuatan sebagaimana yang didakwakan Penuntut Umum, namun Terdakwa SAMAD Bin RABA dinyatakan tidak mampu untuk bertanggung jawab oleh karena adanya gangguan jiwa, sehingga Majelis Hakim melepaskan Terdakwa dari segala tuntutan hukum.

Pertimbangan hukum Majelis Hakim Pengadilan Negeri Bulukumba pemeriksa perkara Nomor 16/ PID.B/2011/PN.BLK dalam menjatuhkan putusan lepas segala tuntutan hukum adalah sebagai berikut $:^{8}$

Menimbang, bahwa sekalipun perbuatan Terdakwa telah memenuhi 
unsur dakwaan kumulatif
Penuntut Umum baik
dakwaan PERTAMA
alternatif KETIGA, dakwaan
KEDUA dan dakwaan
KETIGA namun hal
demikian belum memenuhi
syarat untuk penjatuhan
pidana oleh karena
menurut teori pengetahuan
hukum pidana adanya
perbuatan pidana yang
mempunyai pertanggungan
jawab pidana haruslah
memenuhi dua pasangan
dalam syarat pemidanaan
yaitu dapat dipidananya
perbuatan (strafbaarheid
van het felt) dan dapat
dipidananya orang
(strafbaarheid van de
person), Menimbang, bahwa untuk dapat dipidananya orang (strafbaarheid van de person) maka pelaku perbuatan haruslah mampu bertanggung jawabatas

kesalahannya oleh karena berlakunya suatu azas tiada pidana tanpa kesalahan (keine strafe ohne schuld atau geen straf zonder schuld); Menimbang, bahwa kemampuan bertanggung jawab karena adanya kesalahan pada diri pelaku (subjective guilt) setelah memperhatikán keadaan jiwa pelaku maka kesalahan tersebut dapat dimaafkan atau terdapat adanya alasan penghapus kesalahan (schulduitteluitingsgr ong) ;

Menimbang, bahwa alasan pemaaf yang diatur dalam KUHP diantaranya adalah Pasal 44 ayat (1) yang berbunyi "Barang siapa melakukan perbuatan yang tidak dapat dipertanggung jawabkan kepadanya karena jiwanya cacat dalam pertumbuhan atau terganggu karena penyakit tidak dapat dipidana";

Menimbang,

bahwa berdasarkan keterangan saksi ahli Dr. THEODORUS SINGARA, Sp. KJ. (K) yang melakukan pemeriksaan

psikiatrik dan observasi terhadap Terdakwa ditemukan adanya penumpulan afek, halusinasi auditorik, depersonalisasi dan ide ide curiga ada pihak yang tidak senang dengan Terdakwa

selanjutnya saksi ahli menyimpulkan pada diri Terdakwa ditemukan adanya gangguan jiwa, berat berupa Psikosa Non Organik YTT yang menunjukkan unsur ketidak mampuan untuk bertanggung jawab atas perbuatannya ;

Menimbang, bahwa setelah memperhatikan hal - hal yang menjadi latar belakang terjadinya tindak pidana dalam perkara ini dengan demikian sekalipun Terdakwa terbukti melakukan perbuatan pidana sebagaimana didakwakan Penuntut Umum pada dakwaan PERTAMA alternatif KETIGA yaitu Pasal Pasal 44 ayat (3) UU RI No. 23 Tabun 2004 Tentang Penghapusan Kekerasan Dalam Rumah Tangga dakwaan KEDUA yaitu Pasal 
44 ayat (1) UU RI No. 23 Tahun 2004 Tentang Penghapusan Kekerasan Dalam Rumah Tangga dan dakwaan KETIGA yaitu Pasal 80 ayat (1) UU RI No. 23 Tahun 2002 Tentang Perlindungan Anak akan tetapi pribadi Terdakwa tidak dapat dijatuhi hukuman karena Terdakwa pada saat melakukan perbuatan yang didakwakan telah terganggu pikirannya yang sehat (ziekelijke storing der verstandelijke vermogens) ; Menimbang, bahwa berdasarkan pemeriksaan dipersidangan telah ternyata pada diri Terdakwa dapat ditemukan adanya suatu keadaan yang dapat dipandang sebagai alasan pemaaf dengan demikian pada diri Terdakwa tidak terdapat adanya unsur kesalahan (schuldelement) yang menurut Pasal 44 ayat (1) KUHP Terdakwa tidak dapat dihukum maka dari itu Terdakwa haruslah dilepaskan dari segala tuntutan hukum ;

Menimbang, bahwa dengan memperhatikan Pasal 97 ayat (1) KUHAP oleh karena Terdakwa diputus lepas dari segala tuntutan hukum maka dirinya berhak untuk memperoleh rehabilitasi ;

Menimbang, bahwa menurut Pasal 14 ayat (1) PP Nomor 27 Tahun 1983 Tentang Pelaksanaan KUHAP dimana amar putusan mengenai rehabilitasi adalah "Memulihkan hak Terdakwa dalam kemampuan kedudukan dan harkat serta martabatnya " ;

Majelis Hakim berdasarkan pertimbangan Putusan Nomor 16/ PID.B/2011/PN.BLK

membebankan psikiater/psikolog untuk menyatakan pelaku difabel intelektual/psikosial dapat/tidak dapat dimintakan pertanggungjawaban pidana. $^{9}$ Yaitu keterangan saksi ahli Dr. THEODORUS SINGARA, Sp. KJ. (K) yang melakukan pemeriksaan psikiatrik dan observasi terhadap Terdakwa ditemukan adanya penumpulan Afek, halusinasi auditorik, depersonalisasi dan ide ide curiga ada pihak yang tidak senang dengan Terdakwa selanjutnya saksi ahli menyimpulkan pada diri Terdakwa ditemukan adanya gangguan jiwa, berat berupa Psikosa Non Organik YTT yang menunjukkan unsur ketidak mampuan untuk bertanggung jawab atas perbuatannya.

Deskriptif karena keadaan jiwa itu digambarkan "menurut apa adanya" oleh psikiater. Sedangkan, normatif karena Hakim yang menilai berdasarkan hasil pemeriksaan sebelumnya, sehingga dapat menyimpulkan mampu dan ketidakmampuannya hanyalah sekedar pengertian yang normatif. $^{10}$ Secara sederhana, pembuat undangundang seolah-olah mewajibkan Hakim untuk memutus "tidak dapat dimintakan pertanggungjawaban pidana"

9 Jan Remmelink, 2003,Hukum Pidana,Gramedia Pustaka Utama, Jakarta,hlm. 217.

${ }^{10}$ Ibid. 
dengan dasar adanya hambatan kejiwaan yang dikemukakan oleh psikolog/psikiater. Sehingga Hakim diharuskan untuk meminta bantuan ahli (psikiater/psikolog) untuk mempertanggungjawabkan keputusannya. ${ }^{11}$

Selanjutnya penuntut umum mengajukan kasasi atas putusan tersebut, dalam Putusan Kasasi 2554 K/Pid.Sus/2011 Penuntut Umum berpendapat bahwa seharusnya Hakim Pengadilan Negeri Bulukumba tidak mendasarkan putusan hanya kepada keterangan ahli namun juga harus dengan cermat menilai dan mempertimbangkan alat-alat bukti lainnya yaitu keterangan saksi-saksi dan keterangan Terdakwa sendiri.

Selanjutnya pertimbangan Majelis Hakim tingkat Kasasi dalam Putusan Nomor 2554 K/Pid.Sus/2011 menyatakan bahwa: ${ }^{12}$

Menimbang, bahwa sesuai fakta hukum perbuatan Terdakwa terbukti di persidangan bahwa Terdakwalah pelaku perbuatan penganiayaan sehingga korban meninggal dunia. Namun karena kondisi Terdakwa saat melakukan perbuatan a quo tidak dalam posisi sehat jasmani maupun rohani, berdasarkan physichiatik keterangan dokter yang

${ }^{11}$ Ibid., hlm. 217.

12 Putusan Nomor $2554 \mathrm{~K} /$ Pid.Sus/2011 hlm. 24

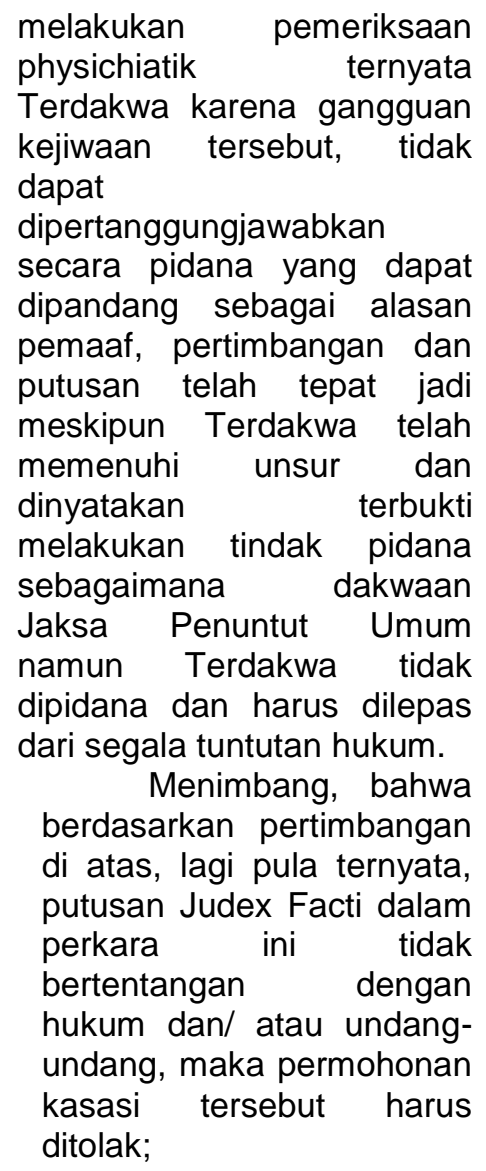

Penerapan Pasal 44 KUHP melalui metode biologis pada hakekatnya tidak dilarang, namun dapat menyebabkan berbagai permasalahan baik peradilan yang tidak adil dan berimbang, ataupun penyelundupan hukum yang dilakukan dengan berpura-pura menjadi oarang gila demi lepasnya dari segala tuntutan. Sehingga landasan atau kerangka berpikir Majelis Hakim dalam perkara a quo menjadi suatu pertanyaan besar. Merupakan suatu yang mustahil Majelis Hakim dapat menilai hubungan kausalitas keadaan intelektual dengan perbuatan yang 
dilakukan, hanya dari suatu pengamatan persidangan.

Majelis Hakim seharusnya mengenali kategori pembagian difabel berdasarkan International Classification of Fungtioning Health and Disability3, sehingga dapat mengetahui karakteristiknya masing-masing. Berangkat dari karakteristik tersebut, maka Majelis Hakim dapat memberikan suatu pertimbangan hukum "apakah perbuatan yang dilakukannya berhubungan dengan hambatan yang dialami oleh diri Terdakwa/pelaku”. Apabila kerangka berpikir ini tidak digunakan oleh Mahkamah Agung, akan timbul banyak unfair trial serta miscarriage of justice.

Alasan

pembenar

menyebabkan sifat melawan hukum perbuatan hilang, baik karena alasan yang ditentukan oleh undang-undang (alasan penghapus melawan hukum formal) maupun diluar undang-undang (alasan penghapus melawan hukum materiil). Pertanggungjawaban pidana ada kecuali ada alasanalasan penghapus pidana tersebut. Perumusan pertanggungjawaban pidana secara negatif dapat terlihat dari ketentuan Pasal 44, 48, 49, 50 dan 51 KUHP. Pertanggung jawaban pidana secara negatif berhubungan dengan fungsi represif hukum pidana. Berpangkal tolak dari ajaran monodualistik (daad en dader strafrecht), proses wajar (due process) penentuan pertanggungjawaban pidana bukan hanya dilakukan dengan memperhatikan kepentingan masyarakat tetapi juga kepentingan pembuatnya sendiri. $^{13}$

Menurut Andi Hamzah, Pasal 44 ayat (1) KUHP berbunyi "Barangsiapa melakukan perbuatan yang tidak dapat dipertanggungkan kepadanya karena jiwanya yang cacat dalam pertumbuhan atau terganggu karena penyakit, tidak dipidana”. ${ }^{14}$ Adapun Pasal 44 ayat (1) KUHP pada KUHP terjemahan R. Soesilo berbunyi "Barangsiapa mengerjakan sesuatu perbuatan, yang tidak dapat dipertanggungkan kepadanya karena kurang sempurna akalnya atau karena sakit berubah akal tidak boleh dihukum". 15

Dalam perkara ini
Majelis Hakim dalam
putusannya melepaskan
Terdakwa SAMAD Bin
RABA dari segala tuntutan
hukum yang artinya tidak
dijatuhi hukuman karena
Terdakwa pada waktu
melakukan perbuatannya

13 Andi Hamzah, 1993. Sistem Pidana dan Pemidanaan di Indonesia. Pradnya Paramita. Jakarta,hlm. 64.

${ }^{14}$ Andi Hamzah, 2012, KUHP\&KUHAP, Rineka Cipta,Jakarta, hlm. 23.

15 R. Soesilo, 1996, Kitab Undang-Undang Hukum Pidana (KUHP) serta KomentarKomentarnya Lengkap Pasal demi Pasal, Politeia,Bogor, hlm. 60. 


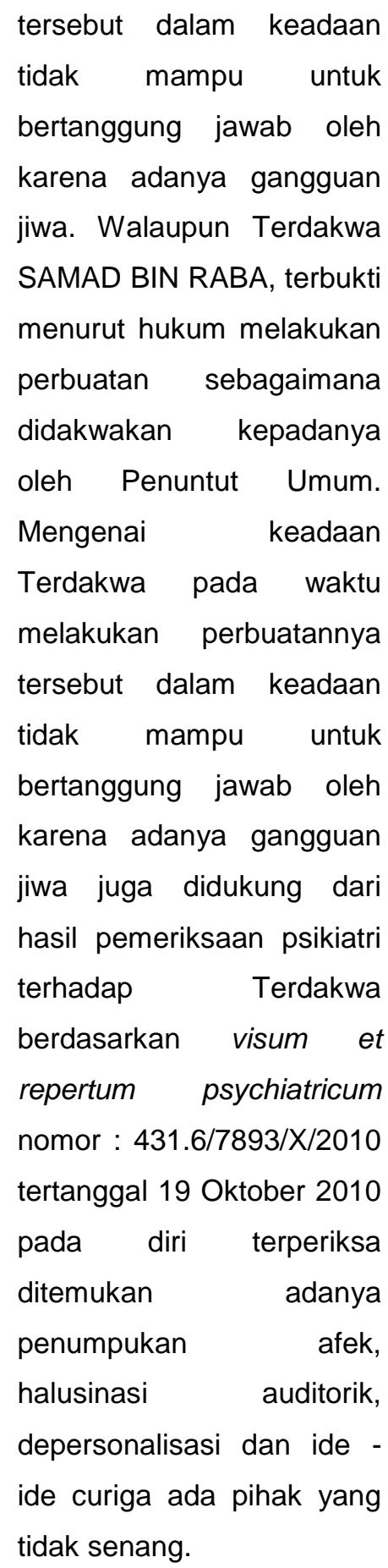

Halusinasi adalah gangguan penyerapan (persepsi) panca indera tanpa adanya rangsangan dari luar yang dapat meliputi semua sistem penginderaan dimana terjadi pada saat individu sadar dengan baik. Pada gangguan skhizofrenia, halusinasi pendengaran (audiotorik) merupakan hal yang paling sering terjadi. Dapat berupa suara bising atau kata-kata yang dapat mempengaruhi tingkah laku, sehingga dapat menimbulkan respon tertentu seperti bicara sendiri, marah atau berespon lain yang membahayakan diri sendiri, orang lain dan lingkungan. ${ }^{16}$ Skhizofrenia adalah penyakit jiwa yang paling banyak terjadi dibandingkan penyakit jiwa lainnya. Penyakit ini menyebabkan kemunduran kepribadian pada umumnya yang biasanya, salah satu gejalanya adalah halusinasi pendengaran dimana si penderita seolah-olah mendengar sesuatu yang sebenarnya tidak ada.

Berdasarkan ketentuan Pasal 191 ayat (1) dan (2) serta Pasal 193 ayat (1) KUHAP, ada dua

\footnotetext{
${ }^{16} \mathrm{http} / / / \mathrm{www} \cdot$ kajianpustaka.com/2013/08/pe ngertian-jenis-dan-tahapan-

halusinasi.html?m=1, (diakses pada tanggal 25 Juli 2017
} 
sifat putusan dalam perkara pidana yaitu : ${ }^{17}$

a. Putusan

pemidanaan, apabila

apa yang

didakwakan oleh

Penuntut Umum

dalam surat

dakwaannya telah

terbukti secara sah

dan meyakinkan

menurut hukum.

b. Putusan yang bukan

pemidanaan dapat

berupa putusan

bebas (vrijspraak)

dan putusan lepas

dari segala tuntutan

hukum (onslagh van

recht vervolging).

Untuk mengetahui dalam keadaan bagaimana putusan bebas dijatuhkan, dapat dilihat dari ketentuan Pasal 191 ayat (1) KUHAP yang berbunyi :

"Jika pengadilan berpendapat bahwa dari hasil pemeriksaan di sidang, kesalahan Terdakwa atau perbuatan yang didakwakan kepadanya tidak terbukti secara sah dan meyakinkan, maka Terdakwa diputus bebas".

${ }^{17}$ Lilik Mulyadi, 1996,Hukum Acara Pidana (Suatu Tinjauan Khusus terhadap Surat Dakwaan, Eksepsi dan Putusan Peradilan),PT. Citra Aditya Bakti, Bandung,hlm. 126-130.
Putusan lepas dari segala tuntutan hukum (onslagh van recht vervolging)diatur dalam Pasal 191 ayat (2) KUHAP, yang berbunyi :

"Jika pengadilan berpendapat bahwa perbuatan yang didakwakan kepada Terdakwa terbukti, tetapi perbuatan itu tidak merupakan suatu tidak pidana, maka Terdakwa diputus lepas dari segala tuntutan hukum"

Pada putusan jenis ini dapat disebutkan bahwa apa yang didakwakan Penuntut Umum dalam surat dakwaan terbukti secara sah dan meyakinkan menurut hukum akan tetapi Terdakwa tidak dapat dipidana oleh karena perbuatan yang dilakukan bukan merupakan tindak pidana. ${ }^{18}$ Dalam KUHAP tidak ada penjelasan lebih lanjut tentang isi Pasal 191 ayat (2) tersebut. Isi Pasal 191 ayat (2) KUHAP dapat membingungkan oleh karena di satu pihak disebutkan perbuatan yang didakwakan kepada Terdakwa terbukti tetapi perbuatan itu tidak

${ }^{18}$ Ibid.,hlm 130. 


$$
\begin{aligned}
& \text { merupakan perbuatan } \\
& \text { pidana. Hakim tidak boleh } \\
& \text { menjatuhi hukuman bagi si } \\
& \text { pelaku karena terdapat } \\
& \text { keadaan yang membuat } \\
& \text { tindakan dari pelaku } \\
& \text { menjadi tidak bersifat tidak } \\
& \text { melanggar hukum, oleh } \\
& \text { karena pada pelaku } \\
& \text { terdapat unsur schuld } \\
& \text { (kesalahan). }{ }^{19} \\
& \text { Selama ini aturan } \\
& \text { undang-undang } \\
& \text { merumuskan alasan } \\
& \text { penghapus sifat melawan } \\
& \text { hukum bercampur dengan } \\
& \text { alasan penghapus } \\
& \text { kesalahan. } \\
& \text { Pertanggungjawaban } \\
& \text { pidana } \\
& \text { umumnya } \\
& \text { dirumuskan dalam bentuk } \\
& \text { negatif , apabila } \\
& \text { dihubungkan dengan } \\
& \text { melawan hukum melawan } \\
& \text { hukum dalam fungsinya } \\
& \text { yang negatif, maka hal itu } \\
& \text { merupakan alasan } \\
& \text { tambahan untuk } \\
& \text { meniadakan pidana. Dalam } \\
& \text { hal ini alasan-alasan yang } \\
& \text { menyebabkan suatu } \\
& \text { perbuatan sekalipun telah } \\
& \text { memenuhi isi rumusan } \\
& \text { undang-undang mengenai } \\
& \text { suatu tindak pidana tapi } \\
& \text { kemudian karena alasan- }
\end{aligned}
$$

${ }^{19}$ C.Djisman Samosir, 1985,Hukum Acara Pidana dalam Perbandingan,Bina Cipta,Bandung,hlm. 94-95. alasan tersebut, perbuatan itu menjadi dibenarkan. Dalam ilmu hukum disebut sebagai alasan pembenar (justification of crime) yang berbeda dengan alasan pemaaf (excusing of liability) yaitu alasan yang menghapus kesalahan. ${ }^{20}$

2. Kesesuaian

Pertimbangan Hakim

Dalam Memutus Lepas

Dari Segala Tuntutan

Hukum Terhadap Pelaku

Kekerasan Dalam Rumah

Tangga Yang

Menyebabkan Kematian

Pada Putusan Perkara

Nomor 16/

PID.B/2011/PN.BLK

Dengan Tujuan Hukum Pidana

Hakim dalam
melaksanakan tugasnya
harus bebas dan tidak
boleh terpengaruh atau
memihak kepada siapapun.
Jaminan kebebasan ini
diatur dalam berbagai
peraturan, yaitu dalam
Pasal 24 Undang-Undang
Dasar Negara Republik
Indonesia Tahun 1945,

${ }^{20}$ Chairul Huda, 2006, Tiada Pidana Tanpa Kesalahan menuju kepada Tiada Pertanggungjawaban Pidana Tanpa Kesalahan, Kencana Prenada Media Group, Jakarta,hlm. 59. 


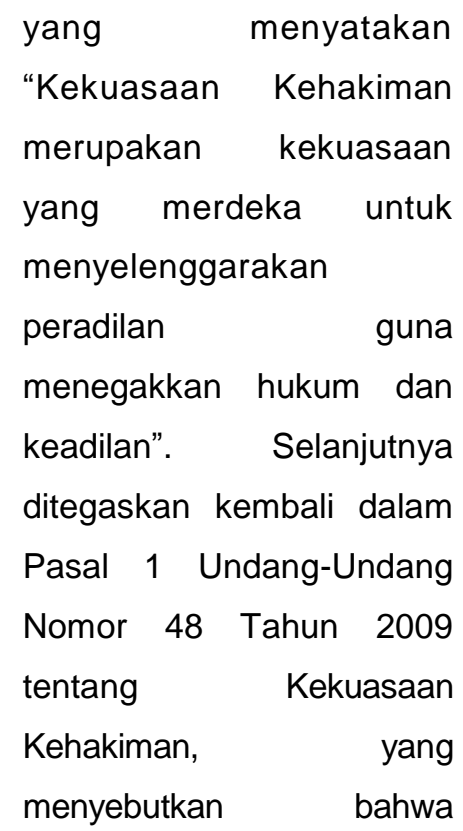

Kekuasaan Kehakiman

adalah Kekuasaan Negara

yang merdeka untuk

menyelenggarakan

peradilan guna

menegakkan hukum dan

keadilan berdasarkan

Pancasila dan Undang-

Undang Dasar Negara

Republik Indonesia Tahun

1945, demi

terselenggaranya Negara

Hukum Republik Indonesia.

Pasal 53 ayat (1) dan (2)

Undang-Undang Nomor 48

Tahun 2009 tentang

Kekuasaan Kehakiman

menyebutkan bahwa dalam

memeriksa dan memutus

perkara, Hakim bertanggung

jawab atas penerapan dan

putusan yang dibuatnya.

Penetapan dan putusan

tersebut harus memuat

pertimbangan Hakim yang

\begin{abstract}
didasarkan pada alasan
dan dasar hukum yang

tepat dan benar. ${ }^{21}$

\begin{tabular}{lr}
\multicolumn{2}{c}{ Hakim memiliki } \\
peranan yang \\
penting & dalam
\end{tabular}

membuktikan suatu perkara

pidana. H.P Panggabean

menyatakan bahwa

terdapat tiga peranan

Hakim dalam persidangan

antara lain peranan Hakim

bersifat legalistik, peranan

Hakim bersifat intuitif

pengadilan dan peranan

Hakim pidana dalam

penerapan hukum

pembuktian. Peranan

Hakim bersifat legalistik dibagi dalam dua aspek::22
\end{abstract}

a. Penerapan hukum melalui penafsiran atas penataan hukum yang berlaku sebagai The living law.

b. Penemuan hukum bagi bidang-bidang hukum yang belum ada peraturan hukumnya (aspek res cottidiane). ${ }^{23}$

Bersamaan dengan

peranan Hakim bersifat

legalistik tersebut,

penerapan hukum

pembuktian telah

${ }^{21}$ Undang-Undang Nomor 48 Tahun 2009 tentang Kekuasaan Kehakiman

${ }_{22}$ H.P. Panggabean, 2012, Hukum Pembuktian (Teori Paktik dan Yurisprudensi Indonesia), Alumni, Bandung,,hlm. 124. 


\begin{abstract}
membebani profesi Hakim untuk melakukan fungsi penegakan hukum itu dengan mendasari semua putusannya sengan tiga unsur pertimbangan intuitif pengadilan, yakni: ${ }^{24}$
\end{abstract}

a. Unsur kepastian hukum (rechtssicherkeit) yang memberi jaminan bahwa hukum itu dijalankan sehinga yang berhak menurut hukum dapat memperoleh haknya dan bahwa putusan seperti itu juga dapat diterapkan untuk jenis perkara yang sama.

b. Unsur kemanfaatan (zweckmassigkeit), bahwa isi putusan itu tidak hanya bermanfaat bagi pihak berpekara tetapi juga bagi masyarakat luas.

c. Unsur keadilan (gerechtigkeit), yang memberi keadilan bagi pihak yang bersangkutan, kalaupun pihak lawan menilainya tidak adil masyarakat harus dapat menerimanya sebagai adil.

Sebagaimana telah diuraikan bahwa, Terdakwa SAMAD Bin RABA dilepaskan dari segala tuntutan karena Terdakwa pada waktu melakukan perbuatannya tersebut

${ }^{24}$ Ibid.,hlm. 127. dalam keadaan tidak mampu untuk bertanggung jawab oleh karena adanya gangguan jiwa. Walaupun Terdakwa SAMAD Bin RABA, terbukti menurut hukum melakukan perbuatan sebagaimana didakwakan kepadanya oleh Penuntut Umum.

Putusan Nomor 16/PID.B/2011/PN.BLK juga dikuatkan dengan Putusan 2554

K/Pid.Sus/2011.Kendati

telah memiliki kekuatan hukum tetap dan dikuatkan melalui putusan kasasi, namun secara akademis apakah putusan tersebut telah sesuai dengan tujuan pemidanaan. Konsepsi dan aplikasi pemidanaan dan hukum berorientasi kepada keadilan. Menurut Aristoteles dalam The Ethics of Aristoteles maka pada dasarnya ada dua teori tentang keadilan yaitu keadilan distributif dan keadilan korektif/komutatif. Keadilan distributif ialah keadilan yang memberikan bagian kepada setiap orang menurut jasanya, dan pembagian mana tidak didasarkan bagian yang sama akan tetapi atas keseimbangan. 


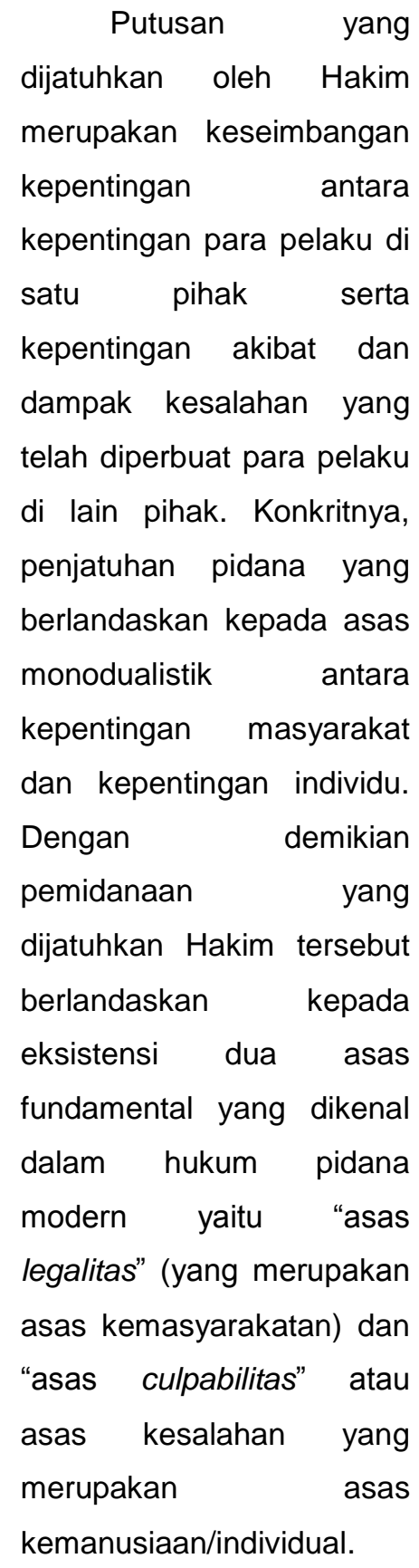

Kedua, secara langsung ataupun tidak langsung, baik implisit maupun eksplisit maka 'filsafat pemidanaan yang bersifat integratif" pada putusan Hakim tidak semata-mata bertumpu, bertitik tolak dan hanya mempertimbangkan aspek yuridis (formal

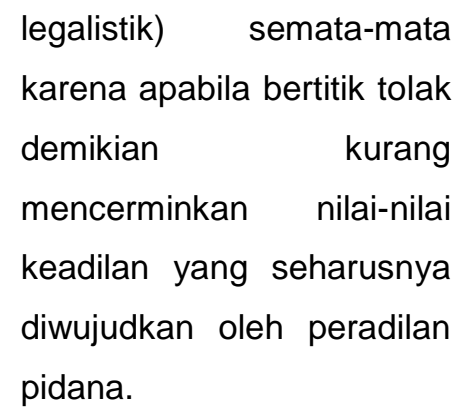

${ }^{25}$ Soedjono, 1981, Petanggungjawaban dalam Hukum Pidana.,Alumni, Bandung, hlm. 5 . 
keadilan. Diantara para sarjana hukum menyatakan bahwa tujuan hukum pidana adalah $:^{26}$

a. Untuk menakutnakuti orang jangan sampai melakukan kejahatan, baik secara menakutnakuti orang banyak (generale preventie), maupun secara menakut-nakuti orang tertentu yang sudah menjalankan kejahatan agar dikemudian hari tidak melakukan kejahatan lagi (speciale preventie), atau

b. Untuk mendidik atau memperbaiki orangorang yang sudah menandakan suka melakukan kejahatan, agar menjadi orang yang baik tabiatnya, sehingga bermanfaat bagi masyarakat.

Terdakwa SAMAD Bin RABA sebagai orang yang menderita gangguan jiwa meskipun perbuatannya terbukti

${ }^{26}$ Wirjono Prodjodikoro, 1981, Asas-Asas Hukum Pidana di Indonesia Cetakan Ke-3, PT. Eresco Jakarta, Bandung, hlm. 16. namun karena adanya

ketidakmampuan dia bertanggung jawab akhirnya diputus lepas dari segala tuntutan hukum. SAMAD Bin RABA tidak dapat menentukan mana yang baik dan mana yang buruk. Narapidana tidak lagi dianggap sebagai orang yang bersalah yang harus menerima penderitaan semata, namun harus dibina dan dibimbing menjadi lebih baik. Sehingga pemidanaan inipun dapat mengarahkan agar dikemudian hari kejahatan yang dilakukan oleh seseorang tidak diulangi kembali baik oleh si pelaku maupun oleh orang lain. ${ }^{27}$ Menurut Saharjo $^{28}$, sebagaimana yang dikutip oleh Sri Wulandari,mengatakan:

"Bahwa tidak saja masyarakat diayomi terhadap perbuatan jahat oleh narapidana, melainkan juga orang yang telah tersesat diayomi dengan memberikan kepadanya bekal hidup sebagai warga yang berguna di dalam

\footnotetext{
${ }^{27}$ Andi Hamzah dan Siti Rahayu, 1983,Suatu Tinjauan Ringkas Sistem Pemidanaan di Indonesia, Akademika Pressindo, Jakarta, hlm. 26.

28 Sri Wulandari, Efektifitas Pembinaan Narapidana di Lembaga Pemasyarakatan Terhadap Tujuan Pemidanaan, Jurnal Pemasyarakatan Indonesia, UNTAG Semarang, hlm. 2.
} 
masyarakat. Orang yang tidak mampu bertanggungjawab atau mengalami ganguan kejiwaan, tidak akan dapat dibina. la tidak dapat mengerti mana yang baik dan mana yang buruk, oleh karena itu pemidanaan tidak dapat mengarahkan agar dikemudian hari kejahatan yang dilakukan oleh seseorang tidak diulangi kembali baik oleh si pelaku. Justru ketika ada pemicu baik halusinasi, depersonalisasi dan ide ide curiga/ waham".

Berdasarkan hal tersebut, maka SAMAD Bin RABA tidak cocok apabila dilakukan pemidanaan, karena ia tidak akan paham apa itu pemidanaan. la tidak dapat merasakan hakekat pemidanaan di dalam lembaga pemasyarakatan. Justru ia dapat membahayakan narapidana lain di dalam lembaga pemasyarakatan, ketika pemicu ketidak warasannya kembali muncul. Oleh karenanya putusan ini telah sesuai dengan tujuan hukum pidana diantaranya kepastian hukum pidana.

\section{E. PENUTUP}

\section{Simpulan}

Berdasarkan pembahasan yang telah diuraikan diatas, maka dapat diambil kesimpulan sebagai berikut:

a. Majelis Hakim dalam memutus lepas dari segala tuntutan

hukum terhadap

pelaku kekerasan

dalam rumah tangga

yang menyebabkan

kematian pada

perkara Nomor 16/

PID.B/2011/PN.BLK

menggunakan

keterangan ahli yaitu

dalam hal ini

psikiater sebagai

satu-satunya

landasan untuk

menentukan

pertanggungjawaban

pidana atau dikenal

juga sebagai metode

biologis.

b. Putusan lepas pada

perkara Nomor 16/

PID.B/2011/PN.BLK

telah sesuai dengan

tujuan hukum pidana

salah satunya

tercapai kepastian

hukum terutama bagi

pelaku.

\section{Saran}

a. Sebaiknya Majelis

Hakim dalam

melakukan proses

penilaian perbuatan

dengan kemampuan

pertanggungjawaban

pelaku dilakukan

melalui metode

gabungan baik

meminta keterangan 
Psikiatri dan juga

melakukan

pengamatan khusus

terhadap sebab dan

akibat perbuatan.

b. Bagi Terdakwa yang mengalami

gangguan jiwa

seharusnya jangan

diputus lepas dari

segala tuntutan

hukum namun

dikenai tindakan

yaitu dimasukkan ke

rumah sakit jiwa.

\section{F. DAFTAR PUSTAKA}

Andi Hamzah dan Siti Rahayu. 1983. Suatu Tinjauan Ringkas Sistem Pemidanaan di Indonesia. Akademika Pressindo. Jakarta.

llyas, Amir. 2012. Asas-asas Hukum Pidana. Rangkang Education Yogyakarta \& PuKAP-Indonesia.

Yogyakarta

Daradjat, Zakiah. 2004. Kesehatan Mental. CV. Gunung Agung. Jakarta.

Hamzah, Andi. 2012. KUHP \& KUHAP, Rineka Cipta, Jakarta. Pidana dan Pemidanaan di Indonesia. Pradnya Paramita. Jakarta.

Huda, Chairul. 2006. Tiada Pidana Tanpa Kesalahan menuju kepada Tiada Pertanggungjawaban Pidana Tanpa Kesalahan. Kencana Prenada Media Group. Jakarta.

Moeljatno. 2008. Asas-Asas Hukum Pidana Edisi Revisi. PT Rineka Cipta. Jakarta.
------------. 1983. Perbuatan
Pidana dan
Pertanggungjawaban
Dalam Hukum Pidana. Bina
Aksara. Yogyakarta.
Mulyadi, Lilik. 1996. Hukum Acara Pidana (Suatu Tinjauan Khusus terhadap Surat Dakwaan, Eksepsi dan Putusan Peradilan). PT. Citra Aditya Bakti. Bandung.
Panggabean, H.P. 2012. Hukum Pembuktian (Teori Paktik dan Yurisprudensi Indonesia). Alumni. Bandung.
Prodjodikoro, Wirjono.1981. Asas- Asas Hukum Pidana di Indonesia Cetakan Ke-3. PT. Eresco Jakarta. Bandung.

Remmelink, Jan. 2003. Hukum Pidana. Gramedia Pustaka Utama. Jakarta.

Soedjono.1981.

Petanggungjawaban dalam Hukum Pidana. Alumni. Bandung.

Soesilo. 1996. Kitab UndangUndang Hukum Pidana (KUHP) Serta KomentarKomentarnya Lengkap Pasal Demi Pasal. Politeia. Bogor.

Sri Wulandari, Efektifitas Pembinaan Narapidana di Lembaga Pemasyarakatan Terhadap Tujuan Pemidanaan, Jurnal Pemasyarakatan Indonesia, UNTAG Semarang. 